\title{
The Value of Case Reports in Systematic Reviews from Rare Diseases. The Example of Enzyme Replacement Therapy (ERT) in Patients with Mucopolysaccharidosis Type II (MPS-II)
}

\author{
Miguel Sampayo-Cordero ${ }^{1,2, *}$, Bernat Miguel-Huguet ${ }^{3}$, Andrea Malfettone ${ }^{1,2}$, \\ José Manuel Pérez-García 1,2,4, Antonio Llombart-Cussac 1,2,5, Javier Cortés 1,2,4,6, \\ Almudena Pardo ${ }^{7}$ and Jordi Pérez-López ${ }^{8}$ \\ 1 Medica Scientia Innovation Research (MedSIR), Ridgewood, NJ 07450, USA; \\ andrea.malfettone@medsir.org (A.M.); jose.perez@medsir.org (J.M.P.-G.); \\ antonio.llombart@medsir.org (A.L.-C.); jacortes@vhio.net (J.C.) \\ 2 Medica Scientia Innovation Research (MedSIR), 08018 Barcelona, Spain \\ 3 Department of Surgery, Hospital de Bellvitge, L'Hospitalet de Llobregat, 08907 Barcelona, Spain; \\ hanscastorp77@gmail.com \\ 4 Institute of Breast Cancer, Quiron Group, 08023 Barcelona, Spain \\ 5 Hospital Arnau de Vilanova, Universidad Católica de Valencia “San Vicente Mártir", 46015 Valencia, Spain \\ Vall d'Hebron Institute of Oncology (VHIO), 08035 Barcelona, Spain \\ 7 Albiotech Consultores y Redacción Científica S.L., 28035 Madrid, Spain; a.pardo@albiotech.com \\ 8 Department of Internal Medicine, Hospital Vall d'Hebron, 08035 Barcelona, Spain; \\ jordiperezlopez.eemm@gmail.com \\ * Correspondence: sampayo.mc@gmail.com
}

Received: 3 August 2020; Accepted: 7 September 2020; Published: 10 September 2020

check for updates

\begin{abstract}
Background: Case reports are usually excluded from systematic reviews. Patients with rare diseases are more dependent on novel individualized strategies than patients with common diseases. We reviewed and summarized the novelties reported by case reports in mucopolysaccharidosis type II (MPS-II) patients treated with enzyme replacement therapy (ERT). Methods: We selected the case reports included in a previous meta-analysis of patients with MPS-II treated with ERT. Later clinical studies evaluating the same topic of those case reports were reported. Our primary aim was to summarize novelties reported in previous case reports. Secondary objectives analyzed the number of novelties evaluated in subsequent clinical studies and the time elapsed between the publication of the case report to the publication of the clinical study. Results: We identified 11 innovative proposals in case reports that had not been previously considered in clinical studies. Only two (18.2\%) were analyzed in subsequent nonrandomized cohort studies. The other nine novelties $(81.8 \%)$ were analyzed in later case reports (five) or were not included in ulterior studies (four) after more than five years from their first publication. Conclusions: Case reports should be included in systematic reviews of rare disease to obtain a comprehensive summary of the state of research and offer valuable information for healthcare practitioners.
\end{abstract}

Keywords: systematic review; meta-analysis; randomized clinical trial; nonrandomized study; case report; mucopolysaccharidosis; enzyme replacement therapy; rare disease; clinical studies

\section{Introduction}

Rare diseases and ultra-rare diseases are defined by a prevalence of $\leq 50$ patients and $\leq 1$ patient per 100,000 people, respectively. This low prevalence of such diseases makes the conduction of randomized 
and prospectively designed studies very hard [1,2]. As an example, mucopolysaccharidosis type II (MPS-II) has a prevalence of 1 in 140,000-156,000 patients [3]. In this case, the registries of clinical cases usually are the best option for clinical research [4,5]. Furthermore, in rare diseases, the phenotype and genotype heterogeneity limit the generalization of the data from clinical trials to clinical practice $[1,6]$. Thus, pharmacological treatment of patients with orphan and ultra-orphan drugs is more dependent on individualized strategies than treatment of more prevalent diseases $[7,8]$.

The value of case reports as individual studies has been stated in previous reviews [9]. Investigators have considered that case reports are appropriate to report new clinical findings, generating new hypothesis about pharmacological therapies, educational value, and high applicability in situations where other designs are not feasible. However, case reports are limited by their retrospective, nonblinded, and nonrandomized trial design, constituting a source of biases that could affect the study outcome. Therefore, findings provided by case reports might not be generalizable and could not be useful to establish a cause-effect relationship, with a consequent high risk of over-interpretation [9-11]. Accordingly, it is uncommon to include case reports in systematic reviews and meta-analyses [12,13].

Systematic reviews were developed to ensure that decisions affecting human health would be informed with the complete understanding of the most relevant research evidence. Thus, the purpose of a systematic review is to provide a summary of the state of research knowledge on an intervention, diagnostic test, prognostic factor, or other health or healthcare topics [12]. It has been suggested that novelties about available interventions are published in case reports five or more years earlier than in clinical studies [13]. Accordingly, a detailed review of a health topic should not exclude published clinical reports, especially in the field of rare diseases, where the individualization of treatments or management strategies has a great relevance on clinical practice $[14,15]$.

A systematic review evaluating the efficacy and safety of enzyme replacement therapy (ERT) for treatment of patients with MPS-II has been previously published [2]. The aim of the present study was to review the novelties on outcomes or therapeutic strategies reported in case studies of the mentioned systematic review [2]. Secondary objectives included the number of novelties evaluated in subsequent clinical studies and the time elapsed between the publication of a novelty in a case report and its subsequent inclusion in a clinical study. Consequently, we searched for the latest clinical studies that incorporated the research questions stated by previous case reports.

\section{Methods}

\subsection{Data Sources, Study Selection, and Quality Assessment from the Previous Meta-Analysis of Case Reports}

The case reports selected were previously included in a recent meta-analysis by Sampayo-Cordero M. et al. [2]. The systematic review included case reports of MPS-II patients who were treated with ERT, and the search was carried out in Excerpta Medica Database (EMBASE), Medical Literature Analysis and Retrieval System Online (MEDLINE), The Cochrane Library (Cochrane Database of Systematic Reviews, Cochrane Central Register of Controlled Trials, and Cochrane Methodology Register and Health Technology Assessment Databases), as well as on the Latin American and Caribbean Literature on Health Sciences (LILACS). The search methods, study selection, and quality assessment are deeply described in the mentioned publication [2]. All case reports published up to 31 December 2015 were included in the search. For the current study, we selected all case reports that evaluated a new outcome or a new therapeutic strategy with ERT in MPS-II patients. Case reports excluded objectives that were similar to those described in previous randomized and nonrandomized studies [16-20].

\subsection{Data Search of New Clinical Studies}

The case reports selected from the previous meta-analysis were used to search new clinical studies with the same issue. We searched for the most recent clinical studies that incorporated the novelties proposed by case reports in patients with MPS-II treated with ERT. We searched MEDLINE and GOOGLE (all) for case reports that reported these novelties and retrieved the citations included in sections "cited by" 
or "comment". There was no restriction of dose, treatment duration, administration via (intravenous or intrathecal), type of study design, or language. All published studies up to 1 July 2020 were included in our comprehensive search.

\subsection{Study Selection}

We selected all clinical studies citing the original case report, which accomplished the following selection criteria:

Inclusion criteria:

(1) Clinical studies (randomized or nonrandomized) and case reports of patients with MPS-II treated with ERT.

(2) The study design evaluates as primary, secondary, or exploratory objective the novelty proposed by the case report.

(3) The results reported included data from new patients where the novelty was the object of research.

Exclusion criteria:

(1) Clinical studies or case reports in other diseases or based on treatment without ERT.

(2) Systematic or literature reviews that do not include analyses of new patients.

\subsection{Quality Assessment}

The study was prospectively designed to select the studies that analyzed the novelties proposed by previous case reports on MPS-II. Results of current meta-analysis are reported in accordance with the Preferred Reporting Items for Systematic Reviews and Meta-Analysis (PRISMA) and Meta-Analyses and Systematic Reviews of Observational Studies (MOOSE) guidelines [21,22]. Three investigators (M.S.-C., B.M.-H., and A.P) entered findings into a database, independently reviewed citations/abstracts from the database, and hand searched and selected full relevant articles and documents for data extraction using preset criteria. Discrepancies were resolved through discussion or input from a fourth reviewer (J.P.-L.).

\subsection{Primary Outcome}

The primary outcome was a synthetic description of novelties proposed by the case reports that were selected in the meta-analysis of Sampayo-Cordero M. et al. [2]. We compared the objectives and ERT schedules of each selected case report with those of clinical studies published prior to the meta-analysis [16-20]. The case reports with objectives or therapy strategies equal to those of the clinical studies were not considered. Only the case reports analyzing novel objectives and therapy strategies were described.

\subsection{Secondary Outcomes}

A. The number of novelties proposed by prior case reports evaluated in subsequent clinical studies. The subsequent clinical studies were reported by type of study (randomized, cohort study, and case report).

B. The time between the publication of the case report and the clinical study.

\subsection{Statistical Methods}

Novelties described in each case report were summarized in a narrative format. The number of novelties and clinical studies was reported as number and percentage. The time elapsed between the publication of a case report including a specific novelty and the follow-up clinical study or studies was calculated subtracting the date of the first clinical study to the date of the first case report analyzing such novelty. If there was not a clinical study analyzing that novelty, the cutoff date was 1 July 2020. 


\section{Results}

\subsection{Data Search Results}

An accurate selection of case reports with novelties published by Sampayo-Cordero et al. [2], which included publications through 31 December 2015, identified 27 citations [2]. Of 27 studies identified, 11 were excluded because they evaluated objectives and ERT schedules equivalent to those of previous clinical studies [16-20]. Thus, 16 publications of case reports were included in the study and their summary identified 11 different novelty proposals about ERT in MPS-II patients (primary objective).

Searching for these 16 case reports, we identified 72 following publications. However, 11 of 72 publications analyzed the novelties of these case reports, while the remaining 61 publications were excluded because they did not (see Supplementary Table S1 and Figure 1).

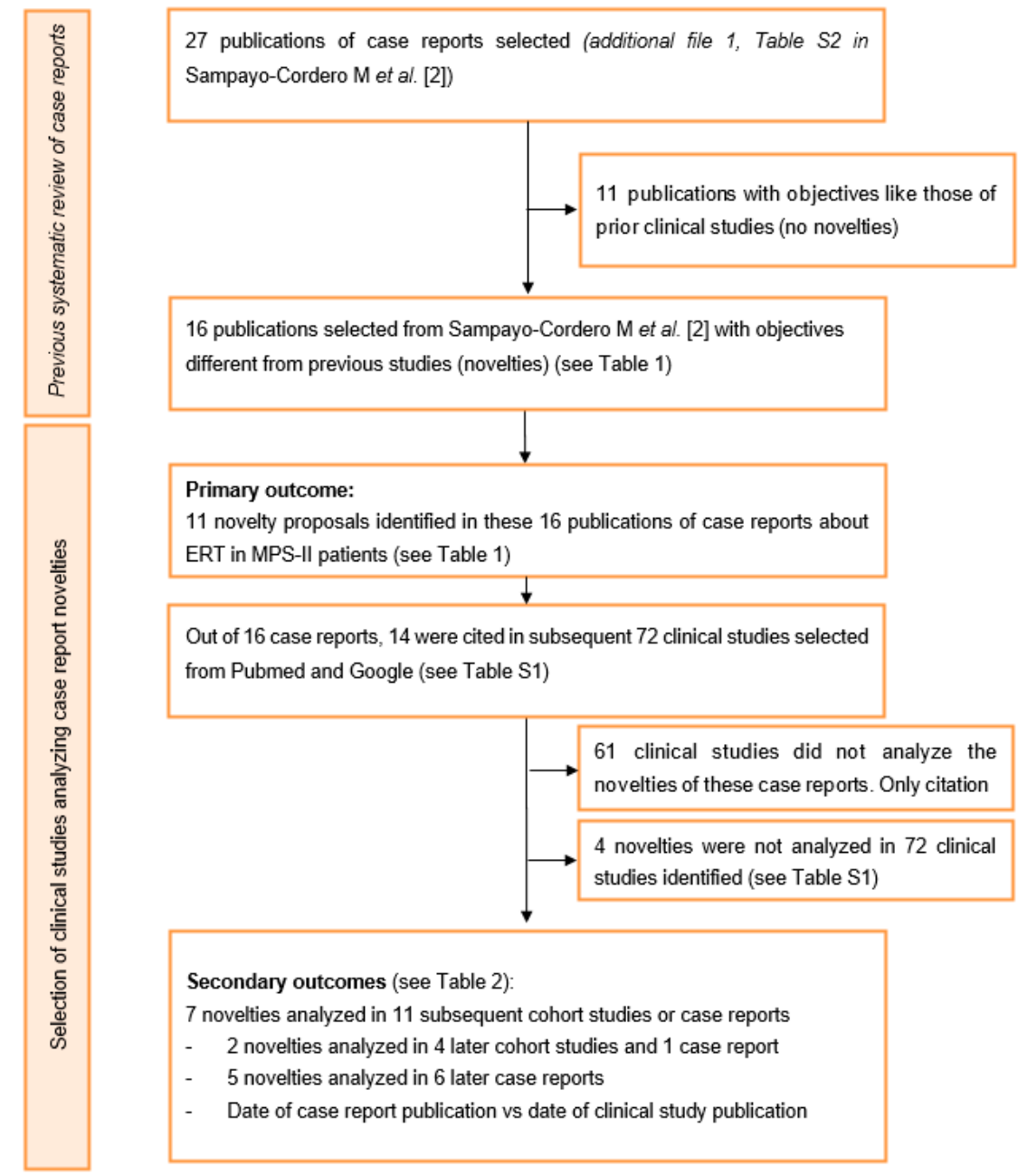

Figure 1. Flow of case reports that evaluated the efficacy and safety of enzyme replacement therapies in mucopolysaccharidosis type II (<2016). ERT—Enzyme replacement therapy; MPS-Mucopolysaccharidosis.

\subsection{Primary Outcome}

Our study identified 11 innovative proposals in case reports that had not been previously considered in clinical studies. Most of them evaluated the efficacy of ERT in different outcomes and therapeutic situations compared with those included in previous clinical studies. They considered skin lesions, hyperactivity, aggressive behavior, language functioning, social interaction, central nervous system development, epileptogenic symptoms, effects in vision, and bone abnormalities. In addition, 
some case reports evaluated the efficacy of ERT in patients with physical abnormalities or affected by hematological diseases. Finally, three studies suggested new therapeutic strategies to increase the immunotolerance for ERT and to reduce dermatan sulfate in plasma (see Table 1) [23-25].

Table 1. Novelties proposed in case reports for enzyme replacement therapy in mucopolysaccharidosis type II patients.

\begin{tabular}{|c|c|}
\hline $\begin{array}{l}\text { Novelties Proposed in Case Reports for Treatment of MPS-II } \\
\text { Patient with ERT * }\end{array}$ & Case Reports Selected \\
\hline \multicolumn{2}{|c|}{ New therapeutic strategies to increase the immunotolerance for ERT } \\
\hline (1) Immune tolerance regimen and desensitization procedures & $\begin{array}{l}\text { Kim et al. 2014; Gkavogiannakis } N \text { et al. } \\
2015[23,24]\end{array}$ \\
\hline $\begin{array}{l}\text { (2) New therapeutic strategies based on the evaluation of } \\
\text { plasmatic dermatan sulfate }\end{array}$ & Volpi et al. 2013 [25] \\
\hline \multicolumn{2}{|c|}{ Different outcomes and therapeutic situations } \\
\hline (3) Effects in pebbling skin lesions & $\begin{array}{l}\text { NoH et al. 2014; Marín LL et al. } \\
2012[26,27]\end{array}$ \\
\hline $\begin{array}{l}\text { (4) Effects in hyperactivity, aggressive behavior, language } \\
\text { functioning, and social interaction }\end{array}$ & Puiu M et al. 2013 [28] \\
\hline $\begin{array}{l}\text { (5) Evaluation of the effects of ERT in central nervous system } \\
\text { development }\end{array}$ & Wang RY et al. 2009 [29] \\
\hline (6) Evaluation of the effects of ERT in epileptogenic symptoms & $\begin{array}{l}\text { Kinoshita M et al. 2014; Bonanni P et al. } \\
2012[30,31]\end{array}$ \\
\hline (7) ERT effects in vision & $\begin{array}{l}\text { Sanchez JI et al. 2015; Lau HA et al. } \\
2015[32,33]\end{array}$ \\
\hline $\begin{array}{l}\text { (8) ERT effect in autoimmune anemia, thrombocytopenia, or } \\
\text { thrombocytopenic purpura }\end{array}$ & Fisher et al. 2015; Uz B et al. $2012[34,35]$ \\
\hline $\begin{array}{l}\text { (9) Botulinum Toxin for the treatment of equinus deformity with } \\
\text { an ERT }\end{array}$ & Nava E et al. 2012 [36] \\
\hline (10) ERT effects in involuntary movements (chorea) & Farooq MU et al. 2008 [37] \\
\hline (11) Early ERT effects in bone abnormalities & Papadia F et al. 2011 [38] \\
\hline \multicolumn{2}{|c|}{$\begin{array}{l}\text { ERT-enzyme replacement therapy, MPS-II-mucopolysaccharidosis type II. *-Only case reports reporting novelties } \\
\text { were analyzed. Case reports excluded analyzed objectives similar to those described in previous randomized } \\
\text { and nonrandomized studies (Muenzer et al. 2006, Muenzer et al. 2011, Tolar J. et al. 2008, Wynn F. et al. 2009, } \\
\text { and Eisengart J.B. et al. 2013) [16-20]. The case reports excluded were: Lampe et al. 2014, Biviana et al. 2014, } \\
\text { Christiano et al. 2013, Sato et al. 2013, Tajima et al. 2013, Hoffmann B. et al. 2011, Tylki-Szymanska et al. 2012, } \\
\text { Pérez-Calvo et al. 2011, Tchan M.C. et al. 2011, Westhoff M. et al. 2011, and Galán Gómez E. et al. 2008 [39-49]. }\end{array}$} \\
\hline
\end{tabular}

\subsection{Secondary Outcomes}

Of 11 novelties, only two (18.2\%) were analyzed in subsequent cohort studies: (1) The efficacy of early ERT in central nervous system and (2) bone abnormalities. The other nine novelties (81.8\%) were analyzed in later case reports (five novelties) or were not included in ulterior studies (four novelties). The five novelties evaluated in new case reports were: (1) The immune tolerance regimen, (2) the effect of ERT in skin, (3) the effect of ERT in epileptogenic symptoms, (4) the effect of ERT in ocular function, and (5) the effect of ERT in hematological diseases. So, novelties proposed in case reports are usually confirmed with later case reports. None of the proposed innovations was included in the objectives of a subsequent randomized clinical trial. In most cases, novel strategies suggested in case reports were not evaluated in a cohort or randomized study after 5 to 12 years (see Table 2). 
Table 2. Clinical studies evaluating novelties proposed by prior case reports.

\begin{tabular}{|c|c|c|}
\hline $\begin{array}{l}\text { Novelties Proposed in Case Reports for } \\
\text { ERT in MPS-II Patients (Citation) }\end{array}$ & $\begin{array}{l}\text { Next Studies, Article Type } \\
\text { (Citation) }\end{array}$ & $\begin{array}{l}\text { Time Until Clinical } \\
\text { Study (Case Reports } \\
\text { not Considered) }\end{array}$ \\
\hline $\begin{array}{l}\text { (1) Immune tolerance regimen and } \\
\text { desensitization procedures }[23,24]\end{array}$ & $\begin{array}{c}\text { Case report } \\
\text { (Julien DC et al., 2020) [50] }\end{array}$ & $\begin{array}{l}\text { No clinical study } \\
\text { after } 6 \text { years }\end{array}$ \\
\hline $\begin{array}{l}\text { (2) New therapeutic strategies based on the } \\
\text { evaluation of plasmatic dermatan sulfate [25] }\end{array}$ & No new citations & $\begin{array}{l}\text { No clinical study } \\
\text { after } 7 \text { years }\end{array}$ \\
\hline (3) Effects in pebbling skin lesions $[26,27]$ & $\begin{array}{c}\text { Case report } \\
\text { (Srinivas SM et al., 2017) [51] }\end{array}$ & $\begin{array}{l}\text { No clinical study } \\
\text { after } 8 \text { years }\end{array}$ \\
\hline $\begin{array}{l}\text { (4) Effects in hyperactivity, aggressive } \\
\text { behavior, language functioning, and social } \\
\text { interaction [28] }\end{array}$ & No clinical study after 7 years & $\begin{array}{l}\text { No clinical study } \\
\text { after } 7 \text { years }\end{array}$ \\
\hline $\begin{array}{l}\text { (5) Evaluation of the effects of ERT in central } \\
\text { nervous system development [29] }\end{array}$ & $\begin{array}{c}\text { Cohort studies } \\
\text { Matsubara et al., 2017; Manara et al., } \\
2011^{* *} \text {; Yund et al., 2015; Tanaka A } \\
\text { et al., 2012 } \\
\text { ( } 3 \text { case reports) } \\
\text { Crowe et al., 2017 [52-56] }\end{array}$ & $\begin{array}{l}2 \text { years/Not } \\
\text { randomized }\end{array}$ \\
\hline $\begin{array}{l}\text { (6) Evaluation of the effects of ERT in } \\
\text { epileptogenic symptoms }[30,31]\end{array}$ & $\begin{array}{c}\text { Case report } \\
\text { Scarpa et al., } 2017 \\
\text { Bonanni et al., } 2014[57,58]\end{array}$ & $\begin{array}{l}\text { No clinical study } \\
\text { after } 8 \text { years }\end{array}$ \\
\hline (7) ERT effects in vision $[32,33]$ & $\begin{array}{c}\text { Case report } \\
\text { (Yamanishi R et al., 2019) [59] }\end{array}$ & $\begin{array}{l}\text { No clinical study } \\
\text { after } 5 \text { years }\end{array}$ \\
\hline $\begin{array}{l}\text { (8) ERT effect in autoimmune anemia, } \\
\text { thrombocytopenia, or thrombocytopenic } \\
\text { purpura }[34,35]\end{array}$ & $\begin{array}{c}\text { Case report } \\
\text { (Alcántara-Ortigoza et al., 2016) [60] }\end{array}$ & $\begin{array}{l}\text { No clinical study } \\
\text { after } 8 \text { years }\end{array}$ \\
\hline $\begin{array}{l}\text { (9) Botulinum Toxin for the treatment of } \\
\text { equinus deformity with an ERT [36] }\end{array}$ & No new citations & $\begin{array}{l}\text { No clinical study } \\
\text { after } 8 \text { years }\end{array}$ \\
\hline $\begin{array}{l}\text { (10) ERT effects in involuntary movements } \\
\text { (chorea) [37] }\end{array}$ & No new citations & $\begin{array}{l}\text { No prospective study } \\
\text { after } 12 \text { years }\end{array}$ \\
\hline $\begin{array}{l}\text { (11) Early ERT effects in bone } \\
\text { abnormalities [38] }\end{array}$ & $\begin{array}{c}\text { Cohort study } \\
\left(\text { Manara R et al., 2011 }{ }^{* *} \text { [ [53] }\right.\end{array}$ & $\begin{array}{l}4 \text { months/Not } \\
\text { randomized }\end{array}$ \\
\hline
\end{tabular}

ERT: Enzyme replacement therapy, MPS-II: Mucopolysaccharidosis type II. * Only case reports reporting novelties were analyzed. Case reports excluded analyzed objectives similar to those described in previous randomized and nonrandomized trials (Muenzer et al. 2006, Muenzer et al. 2011, Tolar J. et al. 2008, Wynn F. et al. 2009, and Eisengart J.B. et al. 2013 [16-20]). The case reports excluded were: Lampe et al. 2014, Biviana et al. 2014, Christiano et al. 2013, Sato et al. 2013, Tajima et al. 2013, Hoffmann B. et al. 2011, Tylki-Szymanska et al. 2012, Pérez-Calvo et al. 2011, Tchan M.C. et al. 2011, Westhoff M. et al. 2011, and Galán Gómez E. et al. 2008 [39-49]. ** This study analyzed two novelties proposed by previous case reports.

\section{Discussion}

In the last years, the interest in case reports by clinical research community as well as the number of journals that publish case reports have increased rapidly [61]. Clinical cases' journals have been included in the Medline database for medical journals and registries of case reports have been developed [9]. The greatest advantages of clinical cases are represented by their ability to detect novelties, the generation of new hypotheses, and their usefulness in the investigation of rare diseases [9]. Additionally, the individualization of therapies and management strategies is a key factor to successfully treat patients with rare diseases. So, new proposals dealing with uncommon situations in the treatment of rare-disease patients have great relevance to translate clinical research into clinical practice $[7,8]$. One of the aims of systematic reviews on therapeutic interventions is to summarize the state of art in this intervention [12]. However, case reports are systematically excluded in systematic reviews in rare-disease research, especially when other designs with a higher level of 
evidence are included [12,15,62-65]. Therefore, important innovations, which could contribute to a better management of the patient treated with orphan drugs, are systematically excluded from systematic reviews of rare diseases [2,13].

Our results on MPS-II patients treated with ERT showed that case reports reported findings relevant to complement patient management. The efficacy of ERT was explored on key outcomes (social behavior, skin lesions, central nervous system development, bone abnormalities, visual acuity) and specific situations (serious respiratory impairment, hematological disease, and physical abnormalities) that had not been considered in previous clinical studies. Additionally, case reports also proposed new therapeutic strategies to deal with immune reactions against ERT [23-38,49]. In accordance with previous results, we observed that most of these novelties were not assessed in subsequent clinical studies after five years from the publication of the case report [13]. Importantly, the new studies assessing these proposals were usually case reports $[31,50,51,57,59,60]$. Therefore, the evidence and innovations provided by case reports will take a long time to be incorporated into clinical studies on rare diseases [13].

Some previous systematic reviews in MPS have included case reports with clinical studies [2,13-15]. As we observed in our results, the inclusion of case reports was necessary to complete the evaluation of the ERT profile in specific situations (pregnancy, ERT discontinuation, surgery interventions, recovering from cerebral infarctions, serious respiratory impairment, or hematological diseases), key alternative outcomes (frequency of respiratory infections, texture of hair and/or skin, skeletal disease, or disease-related hospitalizations), and alternative therapeutic strategies with ERT [2,13-15]. Additionally, the inclusion of case reports allows us to assess the heterogeneity between the patients included in clinical studies and those from clinical cases; and it is useful to evaluate if ERT efficacy and safety results are equivalent among different study designs. The inclusion of case reports allows including all available evidence on ERT and it could increase the power of analyses performed [2,13-15]. We observed in previous systematic reviews including case reports that they used two alternative strategies. The first proposal summarized the results of the case reports and discussed them qualitatively. The results from case reports were not included in meta-analyses $[14,15]$. The second method aggregated the results of case reports in a meta-analysis. The strategy to analyze the results was to define two improvement (or impairment) criteria. One for individual patients included in the meta-analyses (e.g., increase in 6-min walk test over the baseline assessment) and another for the specific outcome or group of patients evaluated (e.g., a significant difference versus a $5 \%$ null hypothesis in the rate of patients with improvement in the walk test) [2,13]. Both methodologies represent an advantage with respect to excluding clinical cases from systematic reviews, since they allow enriching the study's results and conclusions [2,13-15]. Importantly, these studies have demonstrated that standardization and a good definition of outcomes evaluated in case reports increase the validity of their results $[2,13]$. Therefore, the tools to assess the quality of case reports and case series are very relevant in systematic reviews that include clinical cases [66]. Different efforts have been done to homogenize and upgrade the quality of case reports [67] or to search for case reports in clinical databases [9,68].

Previous studies and guidelines have considered that clinical cases could be included in systematic reviews $[2,13,69]$. However, they do not consider the exclusion of case reports a serious concern if there are other designs available. Case report exclusion from systematic reviews in rare diseases has a greater impact than just the loss of a few cases with rare conditions or rare adverse events $[12,69]$. In fact, our analyses show that most of the novelties proposed in case reports are not subsequently contrasted in clinical studies with more patients (after 5 to 12 years), which might be due to the case reports being overlooked, since they are not included in reviews.

Our study took advantage of a previous systematic review to select the individual case reports analyzed in this communication. We considered that this strategy provides an important quality control measure. The selection procedures was previously accepted after a peer review revision [2].

An important point in our strategy for data search was retrieving articles, which cited selected case reports. Some articles could have analyzed novelty of a case report without citing it. However, 
in rare diseases, and in MPS-II disease specifically, the number of clinical studies is quite limited, so it is not likely to happen in many communications [62]. In addition, our study only included case reports from MPS-II patients. Therefore, it is not clear whether the results obtained in this study could be extrapolated to other rare diseases, although it is important to note that the methods for aggregating clinical cases obtained similar results in different MPS, namely MPS-I and MPS-II [2,13-15].

It is usually considered that a MEDLINE search alone is not adequate for answering relevant questions [12]. In accordance, we have increased the scope of our search with GOOGLE searcher, since it is commonly used in all types of searches and has specific tools for systematic reviews and scientific searches $[70,71]$.

\section{Conclusions}

Different authors have underlined the impact of individual clinical reports' results in clinical practice and research [11,72]. Previous studies and guidelines have suggested the inclusion of case reports in systematic reviews, but they did not consider the exclusion of case reports a serious concern if there are other designs available with a higher grade of evidence than case reports [12,69]. However, according to our results, most of the novel procedures proposed in case reports are not evaluated in later clinical studies. Thus, case reports should be included in systematic reviews of rare diseases to make a complete summary of the state of research, since excluding relevant novelties proposed in case reports could reduce the usefulness of the review for clinical practice.

\section{Patents}

A.L.-C. declares the following stock or other ownership: Medica Scientia Innovation Research (MedSIR) and Initia-Research. J.C. declares the following stock, patents, and intellectual property: MedSIR.

Supplementary Materials: The following are available online at http://www.mdpi.com/1660-4601/17/18/6590/s1: Supplementary Table S1. Novelties proposed in case reports of ERT in MPS-II patients and in clinical studies citing these case reports. References [16-20,23-36,39-60,73-132] are cited in the supplementary materials.

Author Contributions: Conceptualization, M.S.-C., B.M.-H., A.P., and J.P.-L.; methodology, M.S.-C., B.M.-H., A.M., J.M.P.-G., A.L.-C., J.C., A.P., and J.P.-L.; software, M.S.-C. and B.M.-H.; validation, M.S.-C., B.M.-H., A.M., J.M.P.-G., A.L.-C., J.C., A.P., and J.P.-L.; formal analysis, M.S.-C., B.M.-H., A.M., J.M.P.-G., and A.P.; investigation, M.S.-C., B.M.-H., A.M., J.M.P.-G., A.L.-C., J.C., A.P., and J.P.-L., data curation, M.S.-C, B.M.-H, A.P., and J.P.-L.; writing-original draft preparation, M.S.-C., B.M.-H., A.M., J.M.P.-G., A.L.-C., J.C., A.P., and J.P.-L.; writing-review and editing, M.S.-C., B.M.-H., A.M., J.M.P.-G., A.L.-C., J.C., A.P., and J.P.-L.; supervision, J.M.P.-G., A.L.-C., J.C., and J.P.-L.; project administration, J.M.P.-G., A.L.-C., J.C., and J.P.-L. All authors critically reviewed and made important intellectual contributions to this manuscript. All authors have read and agreed to the published version of the manuscript.

Funding: This research received no external funding.

Acknowledgments: The authors thank Albiotech consultores S.L. for medical writing. The authors thank the reviewers for their positive comments and careful review, which helped improve the manuscript.

Conflicts of Interest: M.S.-C. reports personal fees from Hospital Vall d'Hebron, Roche, Nestle Health Science, Laboratorios Leti, Medica Scientia Innovation Research (MedSIR), Syntax for Science, Ability Pharma. and Scienco Klinico, outside the submitted work. B.M.-H. declares no competing interests. A.M. is a medical writer in MedSIR. J.M.P.-G. has received consulting and advisor fees from: MedSIR, Roche, and Eli Lilly. A.L.-C. declares the following conflicts of interest: Leadership: Eisai, Celgene, Lilly, Pfizer, Roche, Novartis, and MSD. Stock or other ownership: MedSIR and Initia-Research. Consulting or advisory role: Lilly, Roche, Pfizer, Novartis, Pierre-Fabre, GenomicHealth, and GSK. Speaker's bureau: Lilly, AstraZeneca, and MSD. Research funding: Roche, Foundation Medicine, Pierre-Fabre, and Agendia. Travel, accommodations, expenses: Roche, Lilly, Novartis, Pfizer, and Astra Zeneca. J.C. declares the following conflicts of interest: Consulting/Advisor: Roche, Celgene, Cellestia, AstraZeneca, Biothera Pharmaceutical, Merus, Seattle Genetics, Daiichi Sankyo, Erytech, Athenex, Polyphor, Lilly, Servier, Merck Sharp\&Dohme, GSK, Leuko, Bioasis, and Clovis Oncology. Honoraria: Roche, Novartis, Celgene, Eisai, Pfizer, Samsung Bioepis, Lilly, Merck Sharp\&Dohme, and Daiichi Sankyo. Research funding to the Institution: Roche, Ariad pharmaceuticals, AstraZeneca, Baxalta GMBH/Servier Affaires, Bayer healthcare, Eisai, F.Hoffman-La Roche, Guardanth health, Merck Sharp\&Dohme, Pfizer, Piqur Therapeutics, Puma C, and Queen Mary University of London. Stock, patents, and intellectual property: MedSIR. A.P. has been contracted in the 
past by Shire and by Genzyme. J.P.-L. has received consulting fees, fees as a speaker, and research support from Shire. He is head of Patient Advice and Liaison Service at Centogene AG.

\section{References}

1. Richter, T.; Janoudi, G.; Amegatse, W.; Nester-Parr, S. Characteristics of drugs for ultra-rare diseases versus drugs for other rare diseases in HTA submissions made to the CADTH CDR. Orphanet J. Rare Dis. 2018, 13, 15. [CrossRef] [PubMed]

2. Sampayo-Cordero, M.; Miguel-Huguet, B.; Pardo-Mateos, A.; Malfettone, A.; Pérez-García, J.; Llombart-Cussac, A.; Cortés, J.; Moltó-Abad, M.; Muñoz-Delgado, C.; Pérez-Quintana, M.; et al. Agreement between results of meta-analyses from case reports and clinical studies, regarding efficacy and safety of idursulfase therapy in patients with mucopolysaccharidosis type II (MPS-II). A new tool for evidence-based medicine in rare diseases. Orphanet J. Rare Dis. 2019, 14, 230. [CrossRef] [PubMed]

3. Scarpa, M.; Almássy, Z.; Beck, M.; Bodamer, O.; Bruce, I.A.; De Meirleir, L.; Guffon, N.; Guillén-Navarro, E.; Hensman, P.; Jones, S.; et al. Mucopolysaccharidosis type II: European recommendations for the diagnosis and multidisciplinary management of a rare disease. Orphanet J. Rare Dis. 2011, 6, 72. [CrossRef] [PubMed]

4. Muenzer, J.; Jones, S.A.; Tylki-Szymańska, A.; Harmatz, P.; Mendelsohn, N.J.; Guffon, N.; Giugliani, R.; Burton, B.K.; Scarpa, M.; Beck, M.; et al. Ten years of the Hunter Outcome Survey (HOS): Insights, achievements, and lessons learned from a global patient registry. Orphanet J. Rare Dis. 2017, 12, 1-9. [CrossRef] [PubMed]

5. Muenzer, J.; Giugliani, R.; Scarpa, M.; Tylki-Szymańska, A.; Jego, V.; Beck, M. Clinical outcomes in idursulfase-treated patients with mucopolysaccharidosis type II: 3-year data from the hunter outcome survey (HOS). Orphanet J. Rare Dis. 2017, 12, 1-11. [CrossRef]

6. Frieden, T.R. Evidence for Health Decision Making-Beyond Randomized, Controlled Trials. N. Engl. J. Med. 2017, 377, 465-475. [CrossRef]

7. Stepien, K.M.; Gevorkyan, A.K.; Hendriksz, C.J.; Lobzhanidze, T.V.; Pérez-López, J.; Tol, G.; del Toro Riera, M.; Vashakmadze, N.D.; Lampe, C. Critical clinical situations in adult patients with Mucopolysaccharidoses (MPS). Orphanet J. Rare Dis. 2020, 15, 1-12. [CrossRef]

8. Lampe, C.; Harmatz, P.R.; Parini, R.; Sharma, R.; Teles, E.L.; Johnson, J.; Sivam, D.; Sisic, Z. Enzyme replacement therapy initiated in adulthood: Findings from the mucopolysaccharidosis VIClinical Surveillance Program. Mol. Genet. Metab. 2019, 127, 355-360. [CrossRef]

9. Nissen, T.; Wynn, R. The clinical case report: A review of its merits and limitations. BMC Res. Notes 2014, 7, 264. [CrossRef]

10. Jackson, D.; Daly, J.; Saltman, D.C. Aggregating case reports: A way for the future of evidence-based health care? Clin. Case Rep. 2014, 2, 23-24. [CrossRef]

11. Nakamura, T.; Igarashi, H.; Ito, T.; Jensen, R.T. Important of case-reports/series, in rare diseases: Using neuroendocrine tumors as an example. World J. Clin. Cases 2014, 2, 608-613. [CrossRef] [PubMed]

12. Cochrane Handbook for Systematic Reviews of Interventions|Cochrane Training. Available online: http: //training.cochrane.org/handbook (accessed on 4 February 2018).

13. Sampayo-Cordero, M.; Miguel-Huguet, B.; Pardo-Mateos, A.; Moltó-Abad, M.; Muñoz-Delgado, C.; Pérez-López, J. Agreement between the results of meta-analyses from case reports and from clinical studies regarding the efficacy of laronidase therapy in patients with mucopolysaccharidosis type I who initiated enzyme replacement therapy in adult age: An example of case reports meta-analyses as an useful tool for evidence-based medicine in rare diseases. Mol. Genet. Metab. 2018, 121, 138-149. [CrossRef]

14. Pérez-López, J.; Morales-Conejo, M.; López-Rodríguez, M.; Hermida-Ameijeiras, Á.; Moltó-Abad, M. Efficacy of laronidase therapy in patients with mucopolysaccharidosis type I who initiated enzyme replacement therapy in adult age. A systematic review and meta-analysis. Mol. Genet. Metab. 2017, 121, 138-149. [CrossRef]

15. Pérez-López, J.; Moltó-Abad, M.; Muñoz-Delgado, C.; Morales-Conejo, M.; Ceberio-Hualde, L.; del Toro, M. Efficacy of Idursulfase therapy in patients with Mucopolysaccharidosis type II who initiated enzyme replacement therapy in adult age. A systematic review of the literature. Mol. Genet. Metab. 2018, 124, 216-227. [CrossRef] [PubMed] 
16. Muenzer, J.; Wraith, J.E.; Beck, M.; Giugliani, R.; Harmatz, P.; Eng, C.M.; Vellodi, A.; Martin, R.; Ramaswami, U.; Gucsavas-Calikoglu, M.; et al. A phase II/III clinical study of enzyme replacement therapy with idursulfase in mucopolysaccharidosis II (Hunter syndrome). Genet. Med. 2006, 8, 465-473. [CrossRef]

17. Muenzer, J.; Beck, M.; Eng, C.M.; Giugliani, R.; Harmatz, P.; Martin, R.; Ramaswami, U.; Vellodi, A.; Wraith, J.E.; Cleary, M.; et al. Long-term, open-labeled extension study of idursulfase in the treatment of Hunter syndrome. Genet. Med. 2011, 13, 95-101. [CrossRef]

18. Tolar, J.; Grewal, S.S.; Bjoraker, K.J.; Whitley, C.B.; Shapiro, E.G.; Charnas, L.; Orchard, P.J. Combination of enzyme replacement and hematopoietic stem cell transplantation as therapy for Hurler syndrome. Bone Marrow Transpl. 2008, 41, 531-535. [CrossRef]

19. Wynn, R.F.; Wraith, J.E.; Mercer, J.; O’Meara, A.; Tylee, K.; Thornley, M.; Church, H.J.; Bigger, B.W. Improved Metabolic Correction in Patients with Lysosomal Storage Disease Treated with Hematopoietic Stem Cell Transplant Compared with Enzyme Replacement Therapy. J. Pediatr. 2009, 154, 609-611. [CrossRef]

20. Eisengart, J.B.; Rudser, K.D.; Tolar, J.; Orchard, P.J.; Kivisto, T.; Ziegler, R.S.; Whitley, C.B.; Shapiro, E.G. Enzyme Replacement is Associated with Better Cognitive Outcomes after Transplant in Hurler Syndrome. J. Pediatr. 2013, 162, 375-380.e1. [CrossRef]

21. Liberati, A.; Altman, D.G.; Tetzlaff, J.; Mulrow, C.; Gøtzsche, P.C.; Ioannidis, J.P.A.; Clarke, M.; Devereaux, P.J.; Kleijnen, J.; Moher, D. The PRISMA statement for reporting systematic reviews and meta-analyses of studies that evaluate healthcare interventions: Explanation and elaboration. BMJ 2009, 339, b2700. [CrossRef]

22. Stroup, D.F.; Berlin, J.A.; Morton, S.C.; Olkin, I.; Williamson, G.D.; Rennie, D.; Moher, D.; Becker, B.J.; Sipe, T.A.; Thacker, S.B. Meta-analysis of observational studies in epidemiology: A proposal for reporting. Meta-analysis Of Observational Studies in Epidemiology (MOOSE) group. JAMA 2000, 283, 2008-2012. [CrossRef] [PubMed]

23. Kim, S.; Whitley, C.B.; Jarnes Utz, J.R. Correlation between urinary GAG and anti-idursulfase ERT neutralizing antibodies during treatment with NICIT immune tolerance regimen: A case report. Mol. Genet. Metab. 2017, 122, 92-99. [CrossRef] [PubMed]

24. Gkavogiannakis, N.; Aggelides, N.; Makris, M. Case of infusion reaction to idursulafase and successful re-administration with desensitization. Poster Session Group III-Green TPS 39. Allergy 2015, 70, 527-613. [CrossRef]

25. Volpi, N.; Zampini, L.; Maccari, F.; Santoro, L.; Galeotti, F.; Galeazzi, T.; Gabrielli, O.; Coppa, G.V. Plasmatic kinetics of dermatan sulfate during enzyme replacement therapy with iduronate-2-sulfatase in a mucopolysaccharidosis II Patient. Glycoconj. J. 2013, 30, 727-732. [CrossRef]

26. Noh, T.K.; Han, J.S.; Won, C.H.; Chang, S.; Choi, J.H.; Moon, K.C.; Lee, M.W.; Yang, J.H.; Soung, J.H. Characteristic "pebbling" skin eruption as a presenting sign of Hunter syndrome. Int. J. Dermatol. 2014, 53, e594-e596. [CrossRef]

27. Marín, L.L.; Gutiérrez-Solana, L.G.; Fernández, A.T. Hunter Syndrome: Resolution of Extensive Typical Skin Lesions After 9 Months of Enzyme Replacement Therapy with Idursulfase. Pediatr. Dermatol. 2012, 29, 369-370. [CrossRef]

28. Puiu, M.; Chirita-Emandi, A.; Dumitriu, S.; Arghirescu, S. Hunter syndrome follow-up after 1 year of enzyme-replacement therapy. Case Rep. 2013, 2013, bcr2012007644. [CrossRef]

29. Wang, R.Y.; Cambray-Forker, E.J.; Ohanian, K.; Karlin, D.S.; Covault, K.K.; Schwartz, P.H.; Abdenur, J.E. Treatment reduces or stabilizes brain imaging abnormalities in patients with MPS I and II. Mol. Genet. Metab. 2009, 98, 406-411. [CrossRef]

30. Kinoshita, M.; Furujo, M.; Kubo, T. EEG Evaluation of Mucopolysaccharidosis Type II After Enzyme Replacement Therapy. In Proceedings of the 55th Annual Meeting of the Japanese Society of Neurology, Fukuoka, Japan, 22 May 2014.

31. Bonanni, P.; Gubernale, M.; Martinez, F.; Randazzo, G.; Milantoni, L.; Martinuzzi, A.; Boniver, C.; Vecchi, M.; Scarpa, M. Non-convulsive status epilepticus of frontal origin in mucopolysaccharidosis type II successfully treated with ethosuximide: Case Report. Dev. Med. Child. Neurol. 2012, 54, 961-964. [CrossRef]

32. Sanchez, J.I.; Ascaso, F.J.; Perez, I.; Almenara, C.; Esteban, O.; Martinez, M.; Idoate, A.; Torralba, M.A. Role of SD-OCT in the follow-up of a patient with macular edema associated with mucopoysaccharidosis type II (Hunter syndrome) undergoing idursulfase enzyme replacement therapy. Acta Ophthalmol. 2015, 93. [CrossRef] 
33. Lau, H.A.; Nolan, R.; Narayana, K.; Rucker, J.; Balcer, L.; Galetta, S. Multiple mechanisms of ophthalmologic involvement in attenuated Hunter syndrome: A case report. Mol. Genet. Metab. 2015, 114, S69. [CrossRef]

34. Fisher, A.; Fernandez, K.; Flores, J.; Deshpande, G.; Croke, B.; Antony, R. 2015 ASPHO Abstracts. Autoimmune thrombocytopenia in a patient with hunter syndrome: Should iduronate-2-sulfatase replacement therapy still be considered? Pediatr. Blood Cancer 2015, 62, S21-S119. [CrossRef]

35. Uz, B.; Demiroglu, H.; Ozcebe, O.I. Hunter syndrome and new onset idiopathic thrombocytopenic purpura in a young patient. Ann. Hematol. 2012, 91, 303-304. [CrossRef] [PubMed]

36. Nava, E.; Weber, P.; Gautschi, M.; Nuoffer, J.-M.; Grunt, S. Botulinum Toxin Type A for the Treatment of Equinus Deformity in Patients with Mucopolysaccharidosis Type II. J. Child. Neurol. 2012, 27, 1611-1615. [CrossRef]

37. Farooq, M.U.; Balmer, S.V.; DeRoos, S.T.; Houtman, K.L.; Chillag, K.L. A novel mutation in the iduronate 2 sulfatase gene resulting in mucopolysaccharidosis type II and chorea: Case report of two siblings. Mov. Disord. 2008, 23, 1487-1488. [CrossRef] [PubMed]

38. Papadia, F.; Lozupone, M.S.; Gaeta, A.; Capodiferro, D.; Lacalendola, G. Long-term enzyme replacement therapy in a severe case of mucopolysaccharidosis type II (Hunter syndrome). Eur. Rev. Med. Pharm. Sci 2011, 15, 253-258.

39. Lampe, C.; Atherton, A.; Burton, B.K.; Descartes, M.; Giugliani, R.; Horovitz, D.D.G.; Kyosen, S.O.; Magalhães, T.S.P.C.; Martins, A.M.; Mendelsohn, N.J.; et al. Enzyme Replacement Therapy in Mucopolysaccharidosis II Patients Under 1 Year of Age. In JIMD Reports; Zschocke, J., Gibson, K.M., Brown, G., Morava, E., Peters, V., Eds.; Springer: Heidelberg, Germany, 2014; Volume 14, pp. 99-113. ISBN 978-3-662-43747-6.

40. Bivina, L.; Boyadjiev, S.A. Mucopolysaccharidosis type II (MPS II): Case report of three affected siblings. Mol. Genet. Metab. 2014, 111, S27. [CrossRef]

41. Christianto, A.; Watanabe, H.; Nakajima, T.; Inazu, T. Idursulfase enzyme replacement therapy in an adult patient with severe Hunter syndrome having a novel mutation of iduronate-2-sulfatase gene. Clin. Chim. Acta 2013, 423, 66-68. [CrossRef]

42. Sato, Y.; Fujiwara, M.; Kobayashi, H.; Ida, H. Massive Accumulation of Glycosaminoglycans in the Aortic Valve of a Patient with Hunter Syndrome During Enzyme Replacement Therapy. Pediatr. Cardiol. 2013, 34, 2077-2079. [CrossRef]

43. Tajima, G.; Sakura, N.; Kosuga, M.; Okuyama, T.; Kobayashi, M. Effects of idursulfase enzyme replacement therapy for Mucopolysaccharidosis type II when started in early infancy: Comparison in two siblings. Mol. Genet. Metab. 2013, 108, 172-177. [CrossRef]

44. Hoffmann, B.; Schulze-Frenking, G.; Al-Sawaf, S.; Beck, M.; Mayatepek, E. Hunter Disease Before and During Enzyme Replacement Therapy. Pediatr. Neurol. 2011, 45, 181-184. [CrossRef] [PubMed]

45. Tylki-Szymanska, A.; Jurecka, A.; Zuber, Z.; Rozdzynska, A.; Marucha, J.; Czartoryska, B. Enzyme replacement therapy for mucopolysaccharidosis II from 3 months of age: A 3-year follow-up: Enzyme replacement therapy for mucopolysaccharidosis II. Acta Paediatr. 2012, 101, e42-e47. [CrossRef] [PubMed]

46. Pérez-Calvo, J.; Bergua Sanclemente, I.; López Moreno, M.J.; Torralba Cabeza, M.Á.; Amores Arriaga, B. Respuesta precoz a idursulfasa en un paciente de 31 años de edad con síndrome de Hunter. Rev. Clín. Española 2011, 211, e42-e45. [CrossRef]

47. Tchan, M.C.; Devine, K.T.; Sillence, D.O. Three Adult Siblings with Mucopolysaccharidosis Type II (Hunter Syndrome): A Report on Clinical Heterogeneity and 12 Months of Therapy with Idursulfase. In JIMD Reports_Case and Research Reports, 2011/1; JIMD Reports; SSIEM, Ed.; Springer: Berlin/Heidelberg, Germany, 2011; Volume 1, pp. 57-64. ISBN 978-3-642-17707-1.

48. Galán-Gómez, E.; Guerrero-Rico, A.; Cáceres-Marzal, C.; Zambrano-Castaño, M.; Moreno-Tejero, M.-L.; Grande-Tejada, A.-M.; Fernández-Hernández, S.; Vaquerizo-Madrid, J.; Cardesa-García, J.J. Early response to idursulfase treatment in a 3 year-old boy affected of Hunter syndrome. Eur. J. Med Genet. 2008, 51, $268-271$. [CrossRef] [PubMed]

49. Westhoff, M.; Litterst, P. Successful Noninvasive Ventilation and Enzyme Replacement Therapy in an Adult Patient with Morbus Hunter. In JIMD Reports—Case and Research Reports, 2012/2; JIMD Reports; SSIEM, Ed.; Springer: Berlin/Heidelberg, Germany, 2011; Volume 5, pp. 77-82. ISBN 978-3-642-28095-5.

50. Julien, D.C.; Woolgar, K.; Pollard, L.; Miller, H.; Desai, A.; Lindstrom, K.; Kishnani, P.S. Immune Modulation for Enzyme Replacement Therapy in A Female Patient with Hunter Syndrome. Front. Immunol. 2020, 11, 1000. [CrossRef] [PubMed] 
51. Srinivas, S.; Maganthi, M.; Sanjeev, G. Pebbling of skin: Cutaneous marker of Hunter syndrome. Indian Dermatol. Online J. 2017, 8, 62. [CrossRef] [PubMed]

52. Matsubara, Y.; Miyazaki, O.; Kosuga, M.; Okuyama, T.; Nosaka, S. Cerebral magnetic resonance findings during enzyme replacement therapy in mucopolysaccharidosis. Pediatr. Radiol. 2017, 47, 1659-1669. [CrossRef]

53. Manara, R.; Priante, E.; Grimaldi, M.; Santoro, L.; Astarita, L.; Barone, R.; Concolino, D.; Di Rocco, M.; Donati, M.A.; Fecarotta, S.; et al. Brain and spine MRI features of Hunter disease: Frequency, natural evolution and response to therapy. J. Inherit. Metab. Dis. 2011, 34, 763-780. [CrossRef]

54. Yund, B.; Rudser, K.; Ahmed, A.; Kovac, V.; Nestrasil, I.; Raiman, J.; Mamak, E.; Harmatz, P.; Steiner, R.; Lau, H.; et al. Cognitive, medical, and neuroimaging characteristics of attenuated mucopolysaccharidosis type II. Mol. Genet. Metab. 2015, 114, 170-177. [CrossRef]

55. Crowe, L.; Yaplito-Lee, J.; Anderson, V.; Peters, H. Cognitive and behaviour profiles of children with mucopolysaccharidosis Type II. Cogn. Neuropsychol. 2017, 34, 347-356. [CrossRef]

56. Tanaka, A.; Okuyama, T.; Suzuki, Y.; Sakai, N.; Takakura, H.; Sawada, T.; Tanaka, T.; Otomo, T.; Ohashi, T.; Ishige-Wada, M.; et al. Long-term efficacy of hematopoietic stem cell transplantation on brain involvement in patients with mucopolysaccharidosis type II: A nationwide survey in Japan. Mol. Genet. Metab. 2012, 107, 513-520. [CrossRef] [PubMed]

57. Scarpa, M.; Lourenço, C.M.; Amartino, H. Epilepsy in mucopolysaccharidosis disorders. Mol. Genet. Metab. 2017, 122, 55-61. [CrossRef]

58. Bonanni, P.; Volzone, A.; Randazzo, G.; Antoniazzi, L.; Rampazzo, A.; Scarpa, M.; Nobili, L. Nocturnal frontal lobe epilepsy in mucopolysaccharidosis. Brain Dev. 2014, 36, 826-829. [CrossRef] [PubMed]

59. Yamanishi, R.; Nakamura, N.; Tsunoda, K. Recovery of Vision following Enzyme Replacement Therapy in a Patient with Mucopolysaccharidosis Type II, Hunter Syndrome. Case Rep. Ophthalmol. 2019, 10, 186-194. [CrossRef] [PubMed]

60. Alcántara-Ortigoza, M.A.; García-de Teresa, B.; González-del Angel, A.; Berumen, J.; Guardado-Estrada, M.; Fernández-Hernández, L.; Navarrete-Martínez, J.I.; Maza-Morales, M.; Rius-Domínguez, R. Wide allelic heterogeneity with predominance of large IDS gene complex rearrangements in a sample of Mexican patients with Hunter syndrome: Mutational spectrum in a sample of Mexican MPSII patients. Clin. Genet. 2016, 89, 574-583. [CrossRef]

61. Nissen, T.; Wynn, R. The recent history of the clinical case report: A narrative review. JRSM Short Rep. 2012, 3, 1-5. [CrossRef]

62. Bradley, L.A.; Haddow, H.R.M.; Palomaki, G.E. Treatment of mucopolysaccharidosis type II (Hunter syndrome): Results from a systematic evidence review. Genet. Med. 2017, 19, 1187-1201. [CrossRef]

63. Alegra, T.; Eizerik, D.P.; de Cerqueira, C.C.S.; Pereira, T.V.; Dornelles, A.D.; Schwartz, I.V.D. Eficácia e segurança da terapia com idursulfase em pacientes com mucopolissacaridose tipo II, com e sem comparação com placebo: Revisão sistemática e metanálise. Cad. Saúde Pública 2013, 29, s45-s58. [CrossRef]

64. da Silva, E.M.; Strufaldi, M.W.L.; Andriolo, R.B.; Silva, L.A. Enzyme replacement therapy with idursulfase for mucopolysaccharidosis type II (Hunter syndrome). Cochrane Database Syst. Rev. 2016, 2, 1465-1858. [CrossRef]

65. Almeida, P.H.R.F.; Lemos, L.L.P.D.; Alvares, J.; Godman, B.; Bennie, M.; Acurcio, F.D.A.; Junior, A.A.G. Safety of Enzyme Replacement Therapy for Mucopolysaccharidosis II. In Pharmacoepidemiology and Drug Safety; Wiley: Hoboken, NJ, USA, 2018; pp. 222-223. [CrossRef]

66. Murad, M.H.; Sultan, S.; Haffar, S.; Bazerbachi, F. Methodological quality and synthesis of case series and case reports. BMJ Evid. Based Med. 2018, 23, 60-63. [CrossRef]

67. Gagnier, J.J.; Kienle, G.; Altman, D.G.; Moher, D.; Sox, H.; Riley, D.; The CARE Group; Allaire, A.; Altman, D.G.; Aronson, J.; et al. The CARE guidelines: Consensus-based clinical case reporting guideline development. Case Rep. 2013, 2013, bcr2013201554. [CrossRef]

68. Luo, M.; Cohen, A.M.; Addepalli, S.; Smalheiser, N.R. Identifying main finding sentences in clinical case reports. Database 2020, 2020. [CrossRef] [PubMed]

69. Penedones, A.; Alves, C.; Batel Marques, F. A comparison between two recommendations to conduct and report systematic reviews on drug's safety. Syst. Rev. 2019, 8, 238. [CrossRef] [PubMed] 
70. Piasecki, J.; Waligora, M.; Dranseika, V. Google Search as an Additional Source in Systematic Reviews. Sci. Eng. Ethics 2017, 24, 809-810. [CrossRef]

71. Lakhani, H.V.; Pillai, S.S.; Zehra, M.; Sharma, I.; Sodhi, K. Systematic Review of Clinical Insights into Novel Coronavirus (CoVID-19) Pandemic: Persisting Challenges in U.S. Rural Population. Int. J. Environ. Res. Public Health 2020, 17, 4279. [CrossRef]

72. Cook, M.C. Medical case reports in the age of genomic medicine. Clin. Transl. Immunol. 2015, 4, e45. [CrossRef]

73. Parini, R.; Deodato, F. Intravenous enzyme replacement therapy in mucopolysaccharidoses: clinical effectiveness and limitations. Int. J. Mol. Sci. 2020, 21, 2975. [CrossRef]

74. Chen, H.H.; Sawamoto, K.; Mason, R.W.; Kobayashi, H.; Yamaguchi, S.; Suzuki, Y.; Orii, K.; Orii, T.; Tomatsu, S. Enzyme replacement therapy for mucopolysaccharidoses; past, present, and future. J. Hum. Genet. 2019, 64, 1153-1171. [CrossRef]

75. Sawamoto, K.; Stapleton, M.; Alméciga-Díaz, C.J.; Espejo-Mojica, A.J.; Losada, J.C.; Suarez, D.A.; Tomatsu, S. Therapeutic options for mucopolysaccharidoses: current and emerging treatments. Drugs 2019, 79, 1103-1134. [CrossRef]

76. MPS Consensus Programme Steering Committee; MPS Consensus Programme Co-Chairs; Akyol, M.U.; Alden, T.D.; Amartino, H.; Ashworth, J.; Belani, K.; Berger, K.I.; Borgo, A.; Braunlin, E.; et al. Recommendations for the management of MPS IVA: Systematic evidence- and consensus-based guidance. Orphanet J. Rare Dis. 2019, 14. [CrossRef]

77. Lagler, F. Innovative Treatments for Mucopolysaccharidoses. J. Child Sci. 2018, 8, e163-e171. [CrossRef]

78. Lagler, F.B. Current and Emerging Therapies for Mucopolysaccharidoses. In Pediatric Pharmacotherapy; Kiess, W., Schwab, M., van den Anker, J., Eds.; Handbook of Experimental Pharmacology; Springer International Publishing: Cham, Switzerland, 2019; Volume 261, pp. 39-56. ISBN 978-3-030-50493-9.

79. Singh, A.; Prasad, R.; Mishra, O.P. Spectrum of lysosomal storage disorders at tertiary centre: Retrospective case-record analysis. J. Ped. Genet. 2020, 9, 87-92. [CrossRef] [PubMed]

80. Kubaski, F.; de Oliveira Poswar, F.; Michelin-Tirelli, K.; Burin, M.G.; Rojas-Málaga, D.; Brusius-Facchin, A.C.; Leistner-Segal, S.; Giugliani, R. Diagnosis of mucopolysaccharidoses. Diagnostics 2020, 10, 172. [CrossRef]

81. Tjarks, B.J.; Gardner, J.M.; Riddle, N.D. Hamartomas of skin and soft tissue. Semin. Diag. Pathol. 2019, 36, 48-61. [CrossRef] [PubMed]

82. Almassi, G.H.; Algahim, M. Current and emerging management options for patients with Morquio A syndrome. Ther. Clin. Risk Manag. 2013, 45. [CrossRef]

83. Valayannopoulos, V.; Wijburg, F.A. Therapy for the mucopolysaccharidoses. Rheumatology 2011, 50, v49-v59. [CrossRef] [PubMed]

84. D'Aco, K.; Underhill, L.; Rangachari, L.; Arn, P.; Cox, G.F.; Giugliani, R.; Okuyama, T.; Wijburg, F.; Kaplan, P. Diagnosis and treatment trends in mucopolysaccharidosis I: Findings from the MPS I Registry. Eur. J. Ped. 2012, 171, 911-919. [CrossRef]

85. Zafeiriou, D.I.; Batzios, S.P. Brain and Spinal MR imaging findings in mucopolysaccharidoses: A review. Am. J. Neuroradiol. 2013, 34, 5-13. [CrossRef]

86. de Ruijter, J.; de Ru, M.H.; Wagemans, T.; IJlst, L.; Lund, A.M.; Orchard, P.J.; Schaefer, G.B.; Wijburg, F.A.; van Vlies, N. Heparan sulfate and dermatan sulfate derived disaccharides are sensitive markers for newborn screening for mucopolysaccharidoses types I, II and III. Mol. Genet. Metab. 2012, 107, 705-710. [CrossRef]

87. Lin, S.-P.; Lin, H.-Y.; Wang, T.-J.; Chang, C.-Y.; Lin, C.-H.; Huang, S.-F.; Tsai, C.-C.; Liu, H.-L.; Keutzer, J.; Chuang, C.-K. A pilot newborn screening program for Mucopolysaccharidosis type I in Taiwan. Orphanet J. Rare Dis. 2013, 8, 147. [CrossRef]

88. Baldo, G.; Mayer, F.Q.; Martinelli, B.Z.; de Carvalho, T.G.; Meyer, F.S.; de Oliveira, P.G.; Meurer, L.; Tavares, Â.; Matte, U.; Giugliani, R. Enzyme replacement therapy started at birth improves outcome in difficult-to-treat organs in mucopolysaccharidosis I mice. Mol. Genet. Metab. 2013, 109, 33-40. [CrossRef] [PubMed]

89. Higuchi, T.; Shimizu, H.; Fukuda, T.; Kawagoe, S.; Matsumoto, J.; Shimada, Y.; Kobayashi, H.; Ida, H.; Ohashi, T.; Morimoto, H.; et al. Enzyme replacement therapy (ERT) procedure for mucopolysaccharidosis type II (MPS II) by intraventricular administration (IVA) in murine MPS II. Mol. Genet. Metab. 2012, 107, 122-128. [CrossRef] [PubMed] 
90. Dickson, P.I.; Chen, A.H. Intrathecal enzyme replacement therapy for mucopolysaccharidosis I: Translating success in animal models to patients. Current Pharm. Biotechnol. 2011, 12, 946-955. [CrossRef] [PubMed]

91. Reichert, R.; Campos, L.G.; Vairo, F.; de Souza, C.F.M.; Pérez, J.A.; Duarte, J.Á.; Leiria, F.A.; Anés, M.; Vedolin, L.M. Neuroimaging findings in patients with mucopolysaccharidosis: What you really need to know. Radiographics 2016, 36, 1448-1462. [CrossRef]

92. Yang, E.; Prabhu, S.P. Imaging nanifestations of the leukodystrophies, inherited disorders of white matter. Radiol. Clin. N. Am. 2014, 52, 279-319. [CrossRef]

93. Calleja Gero, M.L.; González Gutiérrez-Solana, L.; López Marín, L.; López Pino, M.A.; Fournier Del Castillo, C.; Duat Rodríguez, A. Neuroimaging findings in patient series with mucopolysaccharidosis. Neurología (English Edition) 2012, 27, 407-413. [CrossRef]

94. Coppa, G.V.; Buzzega, D.; Zampini, L.; Maccari, F.; Galeazzi, T.; Pederzoli, F.; Gabrielli, O.; Volpi, N. Effect of 6 years of enzyme replacement therapy on plasma and urine glycosaminoglycans in attenuated MPS I patients. Glycobiology 2010, 20, 1259-1273. [CrossRef]

95. Baldo, G.; Wozniak, D.F.; Ohlemiller, K.K.; Zhang, Y.; Giugliani, R.; Ponder, K.P. Retroviral-vector-mediated gene therapy to mucopolysaccharidosis I mice improves sensorimotor impairments and other behavioral deficits. J. Inherited Metab. Dis. 2013, 36, 499-512. [CrossRef]

96. Renaud, D. Lysosomal Disorders associated with leukoencephalopathy. Sem. Neurol. 2012, 32, $051-054$. [CrossRef]

97. Baldo, G.; Giugliani, R.; Matte, U. Lysosomal enzymes may cross the blood-brain-barrier by pinocytosis: Implications for Enzyme Replacement Therapy. Med. Hypotheses 2014, 82, 478-480. [CrossRef]

98. Grosse, S.D.; Lam, W.K.K.; Wiggins, L.D.; Kemper, A.R. Cognitive outcomes and age of detection of severe mucopolysaccharidosis type 1. Genet. Med. 2017, 19, 975-982. [CrossRef] [PubMed]

99. Arrol, L.P.; Kerrins, A.M.; Yamakawa, Y.; Smith, P.M. Fucosidosis in a domestic shorthair cat. J. Feline Med. Surg. 2011, 13, 120-124. [CrossRef] [PubMed]

100. Ahn, S.Y.; Chang, Y.S.; Sung, D.K.; Ko, A.; Kim, C.H.; Yoo, D.K.; Lim, K.H.; Sohn, Y.B.; Jin, D.K.; Park, W.S. High-dose enzyme replacement therapy attenuates cerebroventriculomegaly in a mouse model of mucopolysaccharidosis type II. J. Hum. Genet. 2013, 58, 728-733. [CrossRef] [PubMed]

101. Jelin, A.C.; O’Hare, E.; Blakemore, K.; Jelin, E.B.; Valle, D.; Hoover-Fong, J. Skeletal Dysplasias: Growing Therapy for Growing Bones. Front. Pharmacol. 2017, 8. [CrossRef] [PubMed]

102. Guillén-Navarro, E.; Blasco, A.J.; Gutierrez-Solana, L.G.; Couce, M.L.; Cancho-Candela, R.; Lázaro, P. Guía de práctica clínica para el tratamiento del síndrome de Hunter. Med. Clín. 2013, 141, 453.e1-453.e13. [CrossRef]

103. Mendez, D.C.; Stover, A.E.; Rangel, A.D.; Brick, D.J.; Nethercott, H.E.; Torres, M.A.; Khalid, O.; Wong, A.M.; Cooper, J.D.; Jester, J.V.; et al. A novel, long-lived, and highly engraftable immunodeficient mouse model of mucopolysaccharidosis type I. Mol. Ther. Methods Clin. Dev. 2015, 2, 14068. [CrossRef]

104. Nicolas-Jilwan, M.; AlSayed, M. Mucopolysaccharidoses: Overview of neuroimaging manifestations. Ped. Radiol. 2018, 48, 1503-1520. [CrossRef]

105. Liang, J.; Singhal, A. Regression of ventriculomegaly following medical management of a patient with Hurler syndrome. J. Neurosurg. Ped. 2016, 17, 537-539. [CrossRef]

106. Ganesh, A.; Al-Murshedi, F.; Al-Zuhaibi, S.; Al-Thihli, K. Ocular Manifestations of Inborn Errors of Metabolism. In The Eye in Pediatric Systemic Disease; Levin, A.V., Enzenauer, R.W., Eds.; Springer International Publishing: Cham, Switzerland, 2017; pp. 359-460. ISBN 978-3-319-18388-6.

107. Gera, K. Characterization of a Mucopolysaccharidosis Type I and GalNAc Transferase Deficiency Double Knockout Mouse 2018. Available online: https:/lib.dr.iastate.edu/cgi/viewcontent.cgi?article=7589\&context= etd. (accessed on 10 September 2020).

108. Valayannopoulos, V. Enzyme replacement therapy in lysosomal storage diseases. In Rare Diseases; Özgüç, M., Ed.; Advances in Predictive, Preventive and Personalised Medicine; Springer: Dordrecht, The Netherlands, 2015; Volume 6, pp. 91-107. ISBN 978-94-017-9213-4.

109. Kubaski, F.; de Oliveira Poswar, F.; Michelin-Tirelli, K.; da Matte, U.S.; Horovitz, D.D.; Barth, A.L.; Baldo, G.; Vairo, F.; Giugliani, R. Mucopolysaccharidosis Type I. Diagnostics 2020, 10, 161. [CrossRef]

110. Kubaski, F. Diagnosis and Therapies for Mucopolysaccharidoses. Doctoral Dissertation. 2017. Available online: https://udspace.udel.edu/bitstream/handle/19716/21745/Kubaski_udel_0060D_12805.pdf?sequence= 1\&isAllowed=y (accessed on 27 July 2020). 
111. Zhao, X.; Huang, Y.; Li, S.; Lin, W.; Zhou, Z.; Liu, L. Quantitative determination of urinary mucopolysaccharide and its clinical application. Chin. J. Children's Health 2010, 11, 885-889. Available online: http://www.cqvip. com/qk/98529a/201011/35809101.html. (accessed on 10 September 2020).

112. Zheng, M.; Tan, J.; Pan, L.; Cai, R. Analysis of clinical features of mucopolysaccharidosis type II. Chinese J. Eugenics Genet. 2013, 110-111. Available online: http://www.cqvip.com/qk/98444x/201301/44774375.html (accessed on 10 September 2020).

113. Wang, L.; Sun, J. The role of prenatal fetal heart monitoring in reducing fetal and neonatal injury. Chinese J. Eugenics Genet. 2013, 62-63. Available online: http://www.cqvip.com/qk/98444x/201301/44774346.html (accessed on 10 September 2020).

114. van der Lee, J.H.; Morton, J.; Adams, H.R.; Clarke, L.; Ebbink, B.J.; Escolar, M.L.; Giugliani, R.; Harmatz, P.; Hogan, M.; Jones, S.; et al. Cognitive endpoints for therapy development for neuronopathic mucopolysaccharidoses: Results of a consensus procedure. Mol. Genet. Metab. 2017, 121, 70-79. [CrossRef] [PubMed]

115. Janzen, D.; Delaney, K.A.; Shapiro, E.G. Cognitive and adaptive measurement endpoints for clinical trials in mucopolysaccharidoses types I, II, and III: A review of the literature. Mol. Genet. Metab. 2017, 121, 57-69. [CrossRef] [PubMed]

116. Kasteleijn- Nolst Trenite, D.; Genton, P.; Brandt, C.; Reed, R.C. The 'Photosensitivity Model' is ( also) a model for focal (partial) seizures. Epilepsy Res. 2017, 133, 113-120. [CrossRef]

117. Kasteleijn-Nolst Trenite, D. Rebuttal to the manuscript by R.J. Porter. Epilepsy Res. 2017, 133, $123-125$. [CrossRef] [PubMed]

118. Brandl, U. Ethosuximid bei strukturellen und läsionellen Epilepsien. Z. Epileptol. 2014, 27, 132-138. [CrossRef]

119. Scarpa, M.; Cinzia, B. Coinvolgimento neurologico nelle MPS. La Rivista delle Malattie Rare. 2013. Nr. 2. Available online: https://malattierare.aou.udine.it/news/articoli/coinvolgimento-neurologico-nelle-mps (accessed on 10 September 2020).

120. Porter, R.J. The photosensitivity model is not a model for partial (focal) seizures-REBUTTAL. Epilepsy Res. 2017, 133, 121-122. [CrossRef]

121. Huang, H. Clinical analysis of status epilepticus secondary to acute cerebral hemorrhage. J. Guangxi Med. Univ. 2013, 5, 777-779. Available online: http://www.cqvip.com/qk/91948a/2013005/47755900.html. (accessed on 10 September 2020).

122. Chen, Z.; Chen, M.; He, J.; Jia, W.; Qin, X. Segmentation of diabetic macular edema for retinal OCT images. In Proceedings of the Optics in Health Care and Biomedical Optics VIII; Luo, Q., Li, X., Tang, Y., Gu, Y., Eds.; SPIE: Beijing, China, 2018; p. 32.

123. Emel, N. Evaluation of hematologic findings in mucopolysaccharidosis cases. Acta Med. Medit. 2020, 797-800. [CrossRef]

124. Panigrahi, I.; Dhanorkar, M.; Didel, S.; Koganti, R.A. Hunter syndrome with persistent thrombocytopenia. BMJ Case Rep. 2019, 12, e226518. [CrossRef] [PubMed]

125. Kuzenkova, L.; Namazova-Baranova, L.; Gevorkyan, A.; Vashakmadze, N.; Podkletnova, T.; Studenikin, V.; Lazurenko, S. The modern view of mucopolysaccharidosis type II in children: a multidisciplinary approach to the problem. Effect. Pharmacother. Pediatrics 2012. Available online: https://umedp.ru/articles/sovremennyy_ vzglyad_na_mukopolisakharidoz_ii_tipa_u_detey_multidistsiplinarnyy_podkhod_k_probleme.html (accessed on 10 September 2020).

126. Pawliuk, C.; Widger, K.; Dewan, T.; Brander, G.; Brown, H.L.; Hermansen, A.-M.; Grégoire, M.-C.; Steele, R.; Siden, H. (Hal) Scoping review of symptoms in children with rare, progressive, life-threatening disorders. BMJ Support. Palliat. Care 2020, 10, 91-104. [CrossRef]

127. Guo, Y.-B.; Pan, H.-D.; Guo, C.-M.; Li, Y.-M.; Chen, L.-M. Identification of a novel mutation of IDS gene from a Chinese pedigree with MPS II. Hereditas (Beijing) 2009, 31, 1101-1106. [CrossRef] [PubMed]

128. Coutinho, M.F.; Lacerda, L.; Alves, S. Glycosaminoglycan storage disorders: A review. Biochem. Res. Int. 2012, 2012, 1-16. [CrossRef] [PubMed]

129. Noh, H.; Lee, J.I. Current and potential therapeutic strategies for mucopolysaccharidoses. J. Clin. Pharm. Ther. 2014, 39, 215-224. [CrossRef] 
130. Tanaka, N.; Kida, S.; Kinoshita, M.; Morimoto, H.; Shibasaki, T.; Tachibana, K.; Yamamoto, R. Evaluation of cerebrospinal fluid heparan sulfate as a biomarker of neuropathology in a murine model of mucopolysaccharidosis type II using high-sensitivity LC/MS/MS. Mol. Genet. Metab. 2018, 125, 53-58. [CrossRef]

131. Zuber, Z.; Jurecka, A.; Jurkiewicz, E.; Kiec-Wilk, B.; Tylki-Szymanska, A. Cervical Spine MRI Findings in Patients with Mucopolysaccharidosis Type II. Pediatr. Neurosurg. 2015, 50, 26-30. [CrossRef]

132. Rout-Pitt, N.B. The Effects of Undegraded Glycosaminoglycans from Mucopolysaccharidoses on Osteoblast Differentiation and Mineralisation In Vitro; University of Adelaide, School of Medicine: Adelaide, Australia, 2015.

(C) 2020 by the authors. Licensee MDPI, Basel, Switzerland. This article is an open access article distributed under the terms and conditions of the Creative Commons Attribution (CC BY) license (http://creativecommons.org/licenses/by/4.0/). 